\title{
ARTICLES
}

\section{A DESCRIPTIVE STUDY TO ASSESS THE FACTORS INFLUENCING THE JOB STRESS AMONG THE INTENSIVE CARE UNIT NURSES AT ERODE, TAMIL NADU, INDIA}

Mrs. D. Thulasimani* | Dr. Ramesh Kumari**

*Ph.D. Scholar, Himalayan University, Itanagar, Arunachal Pradesh, India

${ }^{*}$ Research Guide at Himalayan University, Itanagar, Arunachal Pradesh, India.

DOI: http://doi.org/10.47211/tg.2020.v07i03.003

\section{ABSTRACT}

When the working system is in demand of more efficiency, individual resource stress is felt. Perception of stress occurs when there is a mismatch between the expectations and accomplishment. Because of workload and working environment seen in hospitals, health professionals frequently suffer from stress. In India prevalence of occupational stress amongst nurses has been estimated to be $87.4 \%$. The present study was planned for assessing factors affecting occupational stress among Intensive Care Unit (ICU) nurses. So the Nurse manager and Chief of the hospital should take initiatives to overcome this problem and help them reduce the job stress by providing commensurate workload according to their abilities and lend proper recognition to their efforts and skills, and motivate them to contribute their thoughts to take decisions in their work, assign them responsibilities to do their work and help them improve their relations with their co-workers.

Key Words: Job Stress, Intensive care unit, Workload.

\section{ABOUT AUTHORS:}

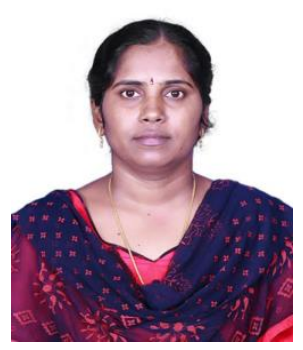

Author Mrs. D. Thulasimani is a Research Scholar at Himalayan University in Itanagar, Arunachal Pradesh, India. She has attended National and International conferences.

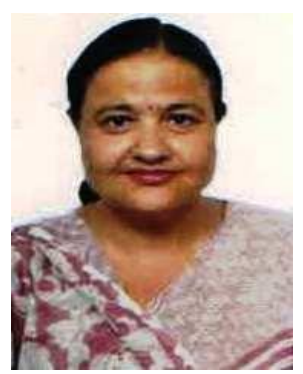

Author Dr. Ramesh Kumari is Research Supervisor in Himalayan University, Itanagar. She has attended and organised Workshops, Seminars and Conferences. She has published various research articles in National and International Journals. 


\section{INTRODUCTION}

Job stress can be the result of physical and emotional responses due to job requirements not matching with abilities, resources or needs of the employees. In other words, it can be defined as an interaction between job environment and characteristics of the employee, when the job requirements exert more pressure on the employee making the person disabled in performing his tasks. Job stress can also result in affecting the employee's health and even hurting him/ her.

Psychological factors besides the chemical, physical and biological risks at the job environment are the main dangers and job stress is very important factor contributing to psychological disorders. United Nation in 1992 declared that job stress is the disease of the $20^{\text {th }}$ century and later, world Health organization referred to it as epidemic. The International Organization of labour estimated the detriment caused by job stress to about $1 \%-3.5 \%$ of national gross production. In different researches it has become clear that about $40 \%$ of workers developed job stress in many countries.

\section{NEED OF THE STUDY}

Nursing is a stressful profession. Care of patients, families, groups, populations or entire communities, with multiple, complex and distressing problems can be overwhelming for even the most experienced person. Nurses regularly face emotionally charged situations and encounter intense interpersonal and inter professional situations and conflict in the workplace while trying to make appropriate and safe decisions. Nursing has been identified as a high-risk occupation in respect of stress-related diseases. Stress can reduce the enjoyment in life, cause hypertension, cardiac problems, reduce immunity, contribute to substance abuse, lead to frustration, irritability and reduce the overall status of mental and physical wellbeing. It is very essential to determine the magnitude of the problem and study the factors responsible for it (Bernard P, 1972). (Garrosa, E. et.al 2008; Decker FH, 1997). Studies done among various healthcare professionals have reported various pre-disposing factors leading to stress. A large sampled study showed that higher educational level, work experience and higher status decreases burnout level while the conflictive interpersonal relations, working at night shifts, difficulty in child care and doing house chores, health problems of the nurse herself, economic hardships and difficulties encountered in transportation are among the factors increasing stress. (Demir A, Ulusoy M, Ulusoy MF, 2003). Stated that low quality care, lowered job satisfaction, increased nurses turnover rates, increased absenteeism and increased health care costs on the part of the patients are some of the problems arising from increased levels of stress among nurses. A study conducted in Brazil concluded that both nurses and hospitals must make efforts to get subsidies for improving assistance conditions and for strategies to cope with stress. (Guerrer FJ, Bianchi ER, 2008). Results of another study in Brazil showed that $57.1 \%$ of nurses consider the ICU a stressful place, and $23.8 \%$ achieved a high score, indicating the presence of stress. The present study is undertaken to assess various factors leading to stress among nurses working in Intensive Care Unit. Occupational stress is common in nursing profession especially among those who are constantly expected to be alert and provide prompt care to patients in intensive care units.

\section{STATEMENT OF THE PROBLEM}

'A Descriptive study to assess the Factors for job stress among the staff nurse working in intensive care units of selected hospital at erode, Tamil Nadu, India.'

\section{OBJECTIVES}

- To assess the various factors for job stress among the staff nurses in intensive care unit.

\section{METHODOLOGY}

A Descriptive research approach with Non-experimental research design was used to assess the factors responsible for occupational stress among the staff nurses in ICU of a selected hospital at Erode. The sample was selected by using the Non-probability Purposive sampling technique, Population consisted of staff nurses working in intensive care units of a selected hospital and who fulfilled the inclusive criteria. The tool used for the present study was Part-A: Demographic variables and Part-B: Expanded nurses stress scale. Data collection was done by the investigator after administering the stress scale to the participants for this study. All the collected data was analysed by using Descriptive and inferential statistics. 


\section{ARTICLES}

\section{RESULT}

The study results concluded that $90 \%$ of staff nurses were in 20-30 years age group, $25 \%$ were in 30-35 years age group. On Gender basis, $95 \%$ were females and $05 \%$ were males. Based on marital status, $55 \%$ were married and $45 \%$ were unmarried and that $90 \%$ had children and $10 \%$ did not have a child. Educational qualification wise, $20 \%$ were B.Sc. $(\mathrm{N})$ and $80 \%$ were GNM. Based on work experience, $30 \%$ staff nurses had $>2$ years' experience, $20 \%$ of nurses had 24-36 months' experience and 50\% of staff nurses with 38 months' and <38 months' experience.

Of the factors responsible for job stress among the intensive care unit staff nurses, (58.62)\% had greater stress due to difficulty in expressing the feelings or opinion about their job conditions to their immediate seniors; (51.72)\% had stress due to too much workload to be completed within a short period; $50.62 \%$ of the staff nurses experienced stress because of lack of appropriate reward for good performance; $48.27 \%$ of subjects reported family or personal life issues as causative factors for occupational stress and finally, about $40 \%$ of them felt stress due to inability to apply their skills in their work performance.

\section{CONCLUSION}

The study findings showed that the level of job stress in most of the staff nurses was of medium level. Job factors were more involved in job stress than the demographic and other factors. So the Nurse manager and Chief of the hospital should take initiatives to overcome this problem and help them reduce the job stress by providing commensurate workload according to their abilities and lend proper recognition to their efforts and skills, and motivate them to contribute their thoughts to take decisions in their work, assign them responsibilities to do their work and help them improve their relations with their co-workers.

\section{REFERENCES}

1. Demir et al.2011. Investigation of factors influencing burnout levels in professional and private life of Journal of Mental Health and Human Behaviour -pg.no-61

2. Guerrer, FJ. et al. 2008 Characterization of stress in intensive care unit nurses. Rev Esc Enferm USP. $355-362$.

3. Preto, VA. et al. 2009 Stress among nurses who work at the intensive care unit. Rev Esc Enferm

4. The Workplace Stress Scale ${ }^{\mathrm{TM}}$ Copyright (C) The Marlin Company, North Haven, CT, and the American Institute of Stress, Yonkers, NY

5. Professional Life Stress scale By David Fontana. Adapted from Managing Stress, The British Psychological Society and Routledge Ltd., 1989.

6. Mehta, RS. Chaudhary, RN. Job related stress among the nurses working in critical care areas at BPKIHS, Nepal. Nursing and Midwifery Research Journal April2005,Vol.1,No.2:70-76

7. Decker, FH. 1997 Occupational and no occupational factors in job satisfaction and psychological distress among nurses. Res Nurse Health 453-64.

8. Golshiri et al. 2012 a comparison of salivary immunoglobulin A between Nurses Working in Emergency Wards and Hospital Clerks. J Isfahan Med Sch. [In Persian] [PubMed] [Google Scholar]

9. McGrath A, Reid N, Boore J. Occupational stress in nursing. International Journal of Nursing Studies. 1989; 26:359-368. [PubMed][Google Scholar]

10. McGrath, A., Reid, N., Boore, J. Occupational stress in nursing. Stud. 2003;40 [PubMed] [Google Scholar 